\title{
PENINGKATAN KETERAMPILAN MEMBACA MELALUI DROP EVERYTHING AND READ (DEAR) PADA SISWA SEKOLAH DASAR (MI)
}

Septia Sugiarsih

Pendidikan Guru Sekolah Dasar (PGSD) Universitas NegeriYogyakarta

Email: Septi_fateen@yahoo.com

\begin{abstract}
ABSTRAK
Keterampilan membaca di sekolah dasar menjadi fondasi atau dasar penentu keberhasilan belajar siswa. Namun sayangnya, keterampilan membaca siswa sekolah dasar di Indonesia memiliki kecenderungan yang rendah. Hasil penelitian PIRLS menunjukkan bahwa keterampilan membaca siswa kelas IV SD di Indonesia menempati urutan ke 41 dari 45 negara. Hasil penelitian EGRA menunjukkan bahwa 50\% dari 4323 siswa kelas III SD di Indonesia dapat membaca (melek huruf), tetapi dari jumlah tersebut hanya setengahnya yang benar-benar memahami apa yang dibaca. Berdasarkan kenyataan tersebut diperlukan suatu upaya untuk meningkatkan keterampilan membaca siswa sekolah dasar (MI) di Indonesia. Salah satu upaya yang dapat dilakukan untuk meningkatkan keterampilan membaca siswa sekolah dasar(MI) adalah melalui DEAR (Drop Everything and Read) yang berarti tinggalkan semua aktivitas dan bacalah. DEAR dapat dijadikan suatu program penggalakan kebiasaan membaca pada siswa melalui program rutin. Pelaksanaan DEAR di sekolah dasar dapat dilakukan dengan meluangkan waktu sejenak di pagi hari sekitar 15-30 menit meninggalakan semua aktivitas untuk membaca. DEAR dilaksanakan oleh seluruh warga sekolah baik siswa, guru, maupun karyawan. Bahan bacaan dalam DEAR dipilih sendiri oleh siswa yang sesuai dengan minat dan tingkat kemampuannya. DEAR membuat siswa senang membaca, gemar membaca, terbiasa membaca, dan menjadikan membaca sebagai kebutuhan sehingga tercipta budaya membaca pada masing-masing siswa baik di lingkungan sekolah maupun di rumah. Melalui DEAR keterampilan membaca siswa akan meningkat.
\end{abstract}

Kata kunci: membaca, DEAR

\begin{abstract}
Reading skills in elementary school are the foundation of student learning success. Unfortunately, the reading skill of elementary school students in Indonesia has a low tendency. The result of PIRLS research shows that the reading skill of fourth grade students of elementary school in Indonesia ranks 41 out of 45 countries. The results
\end{abstract}


of EGRA's research show that $50 \%$ of the 4323 third graders of elementary school in Indonesia can read, but only half of that number who really understand what is read. Based on these facts, it is required an effort to improve the reading skills of elementary school students in Indonesia. One effort that can be done to improve the reading skills of elementary school students is through DEAR (Drop Everything and Read) which means leave all the activity and read. DEAR can be used as a program of reading habit among students through routine program. Implementation of DEAR in elementary school can be done by taking a moment in the morning at about 15-30 minutes to leave all activity to read. DEAR is implemented by all school residents whether students, teachers, or employees. The reading material in DEAR is self-selected by students who match their interests and ability levels. DEAR makes students happy to read, like reading, accustomed to reading, and make reading as a requirement so as to create a culture of reading in each student either in school or at home. Through DEAR students' reading skills will increase.

\section{Keywords: reading, DEAR}

\section{PENDAHULUAN}

Membaca merupakan suatu kegiatan memperoleh makna, informasi, pengetahuan dan pengalaman dari media cetak/tulis baik buku, majalah, ataupun tulisan-tulisan lain. Membaca dapat memperluas wawasan dan pandangan serta meningkatkan daya pikir seseorang. Membaca merupakan sumber belajar yang paling lengkap, paling tersedia, paling murah, paling cepat dan paling mutakhir. Membaca adalah cara yang paling mudah dilakukan untuk mendapatkan informasi baik itu berupa wawasaan, ilmu pengetahuan maupun pengalaman. Melihat hal tersebut, membaca sangat diperlukan oleh siapapun untuk mengembangkan dirinya.

Kemampuan membaca siswa menjadi faktor utama bagi siswa dalam mencerna pembelajaran karena sebagian besar pengetahuan disajikan dalam bahasa tulis. Sehingga mau tidak mau siswa harus memiliki keterampilan dan kemauan untuk membaca guna meningkatkan pengetahuannya. Oleh karena itu, membaca memiliki kedudukan penting dalam dunia pendidikan termasuk dalam kegiatan belajar mengajar karena tanpa adanya kemampuan membaca, siswa akan kesulitan untuk megikuti kegiatan belajar mengajar.

Membaca diajarakan sejak dalam pendidikan dasar, dimulai dari membaca permulaan yang dipelajari siswa di kelas rendah (kelas 1, 2, dan 3) dan membaca lanjut yang dipelajari siswa pada kelas tinggi (kelas 4, 5, dan 6). Keterampilan membaca di sekolah dasar menjadi fondasi atau dasar penentu keberhasilan belajar siswa pada jenjang selanjutnya. Namun pada kenyataannya, keterampilan membaca siswa sekolah dasar di Indonesia memiliki kecenderungan yang rendah.

Rendahnya keterampilan membaca siswa sekolah dasar di Indonesia dapat 
dilihat dari hasil penelitian Progress in International Reading Literacy Study (PIRLS), atau studi internasional dalam bidang membaca pada anak-anak di seluruh dunia yang disponsori oleh The International Association for the Evaluation Achievement, yang diungkapan Srie (2013) dalam USAID ${ }^{59}$. Penelitian ini khususnya dilakukan pada siswa kelas IV SD/MI di Indonesia. Hasil penelitian tersebut menunjukkan bahwa rata-rata anak Indonesia menempati urutan ke 41 dari 45 negara di dunia yang berpartisipasi dalam PIRLS.

Penelitian lain yang menunjukkan rendahnya keterampilan membaca siswa di Indonesia adalah hasil penelitian EGRA (Early Grade Reading Assessment) tahun 2012 di 7 Provinsi mitra Prioritas USAID. Penelitian ini melibatkan 4323 siswa kelas 3. Hasil penelitian ini sesuai dengan yang diungkapkan USAID Prioritas (2014) dalam USAID ${ }^{60}$ menunjukkan bukti bahwa $50 \%$ siswa dapat membaca (melek huruf), tetapi dari jumlah tersebut hanya setengahnya yang benar-benar memahami apa yang dibaca.

Selain keterampilan membaca siswa tergolong maasih rendah, kenyataan juga membuktikan bahwa minat membaca siswa masih tergolong rendah. Terbukti dari riset Progress in International Reading Literacy Study (PIRLS) pada tahun 2006 (Kalida dan Mursyid, 2015: 104) yang menunjukkan bahwa minat membaca anak Indonesia menempati posisi 36 dari 40 negara yang dijadikan sampel. Kenyataan tersebut memang sangat

59 USAID PRIORITAS, Buku Sumber untuk Dosen Lptk Pembelajaran Literasi di Sekolah Dasar/Madrasah Ibtidaiyah (Jakarta: USAID PRIORITAS, 2015), hlm. 31

60 Ibid, hlm. 31 memprihatinkan dan sangat ironis. Siswa lebih banyak menghabiskan waktunya untuk bermain dan menonton televisi serta bermain gadget. Perpustakaan menjadi tempat yang jarang dikunjungi karena siswa lebih memilih bermain ketika jam istirahat. Hal yang lebih memprihatinkan adalah siswa hanya membaca buku ketika akan ulangan atau ujian semester.

Berdasarkan hasil penelitian tersebut dan mengingat pentingnya keterampilan membaca siswa sekolah dasar, maka keterampilan membaca perlu mendapatkan perhatian khusus dari guru maupun praktisi pendidikan untuk ditingkatkan. Keterampilan membaca dapat ditingkatkan melalui menanamkam kebiasaan membaca sejak usia dini. Pembentukan kebiasaan membaca tentu tidak mudah dilakukan. Oleh sebab itu, diperlukan suatu program rutin yang mengatur/mengikat diri siswa untuk membaca. Salah satu kegiatan yang dapat dilakukan untuk menanamkan kebiasaan membaca adalah kegiatan DEAR (Drop Everything and Read). Selain untuk menanamkan kebiasaan membaca, Drop Everything and Read (DEAR) juga mampu meningkatkan keterampilan membaca siswa sekolah dasar (MI).

\section{PEMBAHASAN}

\section{Keterampilan Membaca di Sekolah Dasar}

Keterampilan membaca merupakan salah satu keterampilan yang diajarkan dalam bahasa Indonesia. Pendidikan sekolah dasar menjadi tempat pertama untuk mengajarkan keterampilan membaca. Pendidikan sekolah dasar (SD) di Indonesia merupakan pendidikan yang memberikan bekal kemampuan dasar bagi siswa. Kemampuan dasar tersebut meliputi 
kemampuan membaca, menulis, berhitung, serta pengetahuan dan keterampilan dasar yang sesuai dengan tingkat perkembangan siswa. Hal tersebut diberikan dengan tujuan membekali siswa untuk mempelajari berbagai mata pelajaran, mempersiapkan pendidikan kejenjang yang lebih tinggi, serta memberi bekal bagi kehidupan siswa. Pernyataan di atas sesuai dengan tujuan pedidikan di SD yang disampaikan Ahmad Rofi'uddin dan Darmiyanti Zuhdi $^{61}$, yaitu memberikan bekal kemampuan dasar "baca tulis hitung", pengetahuan dan keterampilan dasar yang bermanfaat bagi siswa sesuai tingkat perkembangannya, guna mempersiapkan siswa mengikuti pendidikan di tingkat selanjutnya. Berdasarkan tujuan tersebut, memberikan bekal dasar keterampilan membaca kepada siswa sekolah dasar menjadi hal yang sangat penting.

Membaca melibatkan banyak hal, tidak sekadar melafalkan tulisan, tetapi juga melibatkan aktivitas visual, berpikir, psikolinguistik, dan metakognitif ${ }^{62}$. Membaca sebagai aktivitas visual merupakan proses menerjemahkan tulisan/huruf ke dalam katakata lisan. Membaca sebagai proses berpikir merupakan aktivitas pengenalan kata dan pemahaman. Tarigan menjelaskan ada dua aspek penting dari membaca yaitu keterampilan yang bersifat mekanis dan keterampilan yang bersifat pemahaman ${ }^{63}$. Keterampilan yang

61 Ahmad Rofi'udin \& Darmiyati Zuchdi, Pendidikan Bahasa dan Sastra Indonesia di Kelas Tinggi (Surabaya: Universitas Negeri Malang, 2001), hlm. 30

62 Farida Rahim, Pengajaran Membaca di Sekolah Dasar (Jakarta: Bumi Aksara, 2007), hlm. 2

63 Henry Gunur Tarigan, Membaca Sebagai Suatu Keterampilan Berbahasa (Bandung: Angkasa, 1985), hlm. 11 bersifat mekanis (mechanical skills) yaitu keterampilan yang mencakup pengenalan bentuk huruf, pengenalan unsur-unsur linguistik, pengenalan hubungan pola ejaan dan bunyi (kemampuan menyuarakan bahan tertulis), dan kecepatan membaca bertaraf lambat. Adapun keterampilan yang bersifat pemahaman (comprehension skills) yaitu keterampilan yang mencakup memahami pengertian sederhana (leksikal, gramatikal, retorikal), memahami signifikasi atau makna, evaluasi atau penilaian dan kecepatan membaca.

Di sekolah dasar membaca dibedakan menjadi dua, yaitu membaca permulaan dan membaca lanjut. Membaca permulaan berlangsung pada kelas awal, yaitu di kelas 1 dan 2 sekolah dasar. Membaca permulaan menekankan pada pengenalan huruf, rangkaian huruf, dan bunyi-bunyi bahasa. Membaca lanjut berlangsung pada jenjang yang lebih tinggi, yaitu pada kelas 3 sampai dengan kelas 6. Membaca lanjut menekankan pada proses memahami bacaan. Tugas guru SD belum berakhir ketika siswa dapat membaca pada membaca permulaan, karena membaca tidak sekadar meyuarakan bunyi-bunyi bahasa. Dalam membaca, pembaca harus memahami bacaan yang sedang dibaca, maksud dari bacaan tersebut dan impilikasinya. Siswa dapat belajar dari suatu teks jika mereka memahami bacaannya, dan sebaliknya, ketika mereka tidak memahami bacaan, mereka tidak dapat belajar dari bacaan tersebut.

Keterampilan membaca di sekolah dasar menjadi fondasi/dasar penentu pencapaian akademik siswa, karena membaca tidak hanya diperlukan dalam pembelajaran bahasa Indonesia melainkan dibutuhkan di semua mata pelajaran, bahkan diperlukan dalam kehidupan sehari-hari. Oleh sebab itu, keterampilan 
membaca di sekolah dasar harus mendapat perhatian khusus dan keterampilan membaca siswa harus terus ditingkatkan.

Meningkatkan keterampilan membaca dapat dilakukan dengan berbagai cara, salah satunya adalah dengan membiasakan siswa membaca dan membuat siswa gemar serta termotivasi untuk membaca. Farida Rahim menyampaikan bahwa siswa yang mempunyai minat tinggi dan gemar membaca akan meningkatkan keterampilan membaca, begitu pula sebaliknya ${ }^{64}$.

Meningkatkan kegemaran membaca pada siswa sekolah dasar dapat dilakukan dengan cara membuat siswa/anak mengakrabi buku dan meningkatkan frekuensi membaca anak. Cara yang dapat dilakukanagaranak mengakrabibuku menurut Ahmad Rofi'uddin dan Darmiyanti Zuhdi adalah menciptakan lingkungan yang menyenangkan, memperkenalkan buku-buku baru, memilih waktu yang tepat, memberi siswa kesempatan untuk merespon isi buku, memberi siswa bimbingan dalam memahami bacaan, memberikan kesempatan untuk mendiskusikan hasil membaca, dan menggunakan cara serta waktu yang bervariasi ${ }^{65}$. Sementara, menurut Setyawan Pujiono dalam Siti Maslakhah, dkk. ${ }^{66}$ upaya yang perlu dilakukan orang tua atau guru untuk meningkatkan frekuensi membaca siswa, yaitu (1) mengenalkan aktivitas membaca sejak dini, (2) menyediakan sumber bacaan yang

64 Farida Rahim, Pengajaran Membaca di Sekolah Dasar (Jakarta: Bumi Aksara, 2007), hlm. 103

65 Ahmad Rofi'udin \& Darmiyati Zuchdi, Pendidikan Bahasa dan Sastra Indonesia di Kelas Tinggi (Surabaya: Universitas Negeri Malang, 2001), hlm. 32

66 Siti Maslakhah, dkk., Bahasa Indonesia (Panduan Menulis Karya Ilmiah (Yogyakarta: Kanwa Publisher, 2011), hlm. 130 cocok dan relevan untuk anak, (3) memberikan cerita-cerita yang menarik dari teks bacaan, (4) memberikan reward (penghargaan) pada anak berupa buku. Selain itu, Setyawan Pujiyono juga memaparkan usaha-usaha yang dapat meningkatkan motivasi membaca yaitu menciptakan budaya membaca, menjadikan kegiatan membaca sebagai suatu kebutuhan dan kewajiban, menjadikan membaca sebagai proses memperkaya diri. Cara-cara tersebut dapat dilakukan melalui program DEAR atau Drop Everything and Read yang dapat membiasakan siswa membaca, kemudian akan meningkatkan kegemaran siswa pada membaca sehingga keterampilan membaca akan meningkat.

DEAR merupakan kegiatan rutin meluangkan waktu sejenak meninggalkan seluruh aktivitas untuk membaca. Membaca yang dilakukan dalam DEAR adalah membaca senyap yang dilakukan secara independen oleh siswa, guru, dan seluruh warga sekolah. Membaca dalam DEAR adalah membaca untuk kesenangan. Buku atau bahan bacaan dalam DEAR dipilih sendiri oleh masingmasing individu/siswa sehingga sesuai dengan minat dan tingkat kemampuan. Buku yang dibaca siswa bukanlah buku pelajaran. Buku yang dipilih dapat berupa buku fiksi maupun nonfiksi, yang telah dipantau guru sehingga buku tersebut layak untuk dibaca siswa.

\section{Pengertian DEAR}

DEAR adalah singkatan dari Drop Everything and Read yang berarti "tinggalkan semua aktivitas dan bacalah". DEAR adalah meluangkan waktu secara teratur dalam jadwal kelas bagi siswa dan guru untuk meninggalkan semua aktivitas dan membaca buku pilihan siswa sendiri, sehingga DEAR dapat mengakomodasi 
berbagai minat dan tingkat kemampuan siswa ${ }^{67}$. Nikki Heath (2017) mendefinisikan DEAR sebagai sesi dimana seluruh sekolah berhenti, meninggalkan apa yang mereka lakukan dan membaca untuk kesenangan selama 20 menit $^{68}$. Alta Allen (2017) menyampaikan bahwa DEAR adalah waktu yang disisihkan setiap hari untuk pembacaan independen baik oleh siswa dan guru $^{69}$. Susan Verner menyatakan bahwa untuk memulai sesi DEAR dalam kelas siswa diberi penjelasan bahwa setiap orang, baik siswa maupun guru akan menghentikan segala aktivitas untuk membaca ${ }^{70}$.

Berdasarkan pengertian-pengertian tersebut dapat disimpulkan bahwa DEAR merupakan kegiatan rutin meluangkan waktu sejenak meninggalkan seluruh aktivitas untuk membaca. Membaca yang dilakukan dalam DEAR adalah membaca senyap yang dilakukan secara independen oleh siswa, guru, dan seluruh warga sekolah. Membaca dalam DEAR adalah membaca untuk kesenangan. Buku atau bahan bacaan dalam DEAR dipilih sendiri oleh masing-masing individu/siswa sehingga sesuai dengan minat dan tingkat kemampuan.

67 Mortimer Adler. Drop Everything and Read. Diakses dari http://www.esl4kids.net/tips/read. html. Pada tanggal 1 Oktober 2017, Jam 21.00 WIB.

68 Nikki Heath. (2017). DEAR - Drop Everything and Read. Diakses dari http://heartoftheschool. edublogs.org/what-we-do/reading-and-literacy/ dear-drop-everything-and-read/. Pada tanggal 30 September 2017, Jam 13.00 WIB.

69 Allen, Alta. (2017). Real-world approaches to reading. Diakses dari http://www.learnnc.org/ lp/pages/769. Pada tanggal 4 Oktober 2017, Jam 20.22 WIB

70 Verner, Susan. (2017). Real World Approaches to Reading 10 Simple Strategies You Can Use Today. Diakses dari http:/busyteacher.org/11907-real-worldreading-approaches-10-simple-strategies.html. Pada tanggal Pada tanggal 4 Oktober 2017, Jam 20.00 WIB.

\section{Lama Waktu dan Jadwal Pelaksanaan DEAR}

Kegiatan DEAR dilakukan secara mandiri dengan membaca senyap selama beberapa menit. Alta Allen (2017) biasanya mengalokasikan waktu 5 menit untuk sesi DEAR di awal tahun, dan meningkat menjadi 10 menit, dan membuat siswa membaca lebih lama seiring tahun berjalan. Biasanya di akhir tahun siswa membaca selama 20 ampai 30 menit. Susan Verner (2017) memulai sesi DEAR selama 5 menit dan akan meningkat lebih lama sesuai dengan peningkatan semester. Traci Gradner (2017) waktu yang digunakan untuk DEAR setiap hari kurang lebih 20 sampai 30 menit. Morteimer Adler (2017) menyampaikan waktu yang digunakan dalam DEAR adalah sepuluh menit sehari untuk siswa yang lebih muda atau dua periode lima belas menit atau dua puluh menit untuk siswa yang lebih tua.

Bagi siswa yang belum pernah melakukan pembacaan senyap sebelumnya, dapat dimulai dengan perlahan dan bertahap, sebagai pengenalan kegiatan DEAR. Pengenalan ini dapat dilakukan dengan memberikan siswa waktu membaca selama 5 menit sehari dan akan terus meningkat seiiring berjalannya waktu. Pada akhirnya DEAR dilakukan secara rutin dan dalam waktu yang singkat kurang lebih 15-30 menit sehari. Jika terlalu lama, dikhawatirkan siswa akan merasa bosan dan tujuan DEAR tidak akan tercapai.

DEAR dilaksanakan secara rutin, dapat diterapkan dalam program harian, mingguan, maupun beberapa hari yang telah dipilih dengan terjadwal secara tetap sehingga siswa mudah untuk mengingatnya. Morteimer Adler (2017) menyatakan DEAR dijadwalkan untuk waktu yang sama setiap hari atau minggu sehingga siswa menyadari bahwa DEAR adalah prioritas 
dan agar mereka dapat menantikan periode khusus ini. Morteimer juga mencontohkan jika waktu DEAR dimulai pukul 2.15 setiap hari Selasa dan Kamis, maka harus dimulai pukul 2.15 setiap hari Selasa dan Kamis, kecuali dalam kasus keadaan darurat.

Jam pelaksanaan DEAR dapat dilakukan kapan saja baik jam sebelum masuk sekolah, disela-sela antara pelajaran, setelah istirahat maupun sebelum pulang sekolah. Namun, hendaknya, jam pelaksanaan DEAR dipilih waktu yang kondusif, agar DEAR dapat terlaksana secara efektif. Waktu yang kondusif untuk dilaksanakannya DEAR biasanya di pagi hari, dimana siswa masih dalam kondisi segar sehingga siswa akan lebih bersemangat membaca.

\section{Peserta DEAR}

DEAR idealnya dilakukan oleh seluruh anggota sekolah (Nikki Heat, 2017). Peserta DEAR jika memungkinkan tidak hanya terbatas pada siswa dan guru, tetapi juga dilakukan oleh seluruh karyawan sekolah. Pembentukan komunitas/lingkungan membaca sangat penting untuk dilakukan. Hal tersebut dilakukan untuk mendorong/memotivsi siswa agar terbiasa dan gemar membaca. Namun, apabila tidak memungkinkan DEAR dapat dilakukan oleh siswa bersama guru di dalam kelas.

\section{Tujuan DEAR}

Tujuan dari DEAR adalah untuk membiasakan siswa gemar membaca, dan menanamkan pada diri siswa bahwa membaca merupakan aktivitas yang menyenangkan. Sesuai dengan pendapat dari Mortimer Adler (2017) bahwa DEAR memiliki tujuan membuat siswa senang membaca dan memastikan bahwa setiap siswa meluangkan beberapa menit dalam setiap harinya untuk membaca secara mandiri bacaan yang diminatinya. Alta Allen (2017) mengemukakan tujuan utama DEAR adalah untuk mendorong siswa membaca secara mandiri untuk waktu yang lama. Tujuan dari DEAR menurut USAID (2015) merupakan upaya penggalakan kebiasaan membaca pada anak melalui program rutin. Dengan tujuan tersebut diharapkan siswa senang membaca, memiliki rasa gemar membaca sehingga tercipta budaya membaca pada masing-masing siswa baik di lingkungan sekolah maupun di rumah, sehingga keterampilan membaca siswa akan meningkat.

\section{Bahan Bacaan DEAR}

Dalam DEAR siswa memilih sendiri buku yang akan mereka baca. Buku bisa dipilih siswa dari perpustakaan atau siswa membawa buku dari rumah. Buku yang dibaca siswa dalam DEAR bukan buku/materi pelajaran, melainkan buku bacaan bebas sesuai minat masing-masing siswa baik yang bertema fiksi maupun nonfiksi. Buku bacaan fiksi dapat berupa cerpen/ novel anak dengan tema tentang kehidupan anak, dongeng anak dengan pesan moral yang terkandung di dalamnya, fabel, dan lain-lain. Buku yang bertema nonfiksi adalah buku-buku pengetahuan tentang makhluk hidup, tokoh, sejarah, agama, teknologi, dan lainnya dengan bahasa yang ringan dan mudah dipahami oleh anak. Setiap siswa harus membawa buku sebelum kegiatan DEAR dimulai

Guru tentu harus memantau dan mengarahkan buku yang pantas untuk dibawa dan dibaca siswa. Guru sebaiknya memberi arahan sebelum siswa membawa buku dari rumah, hal tersebut untuk menghindari kemungkinan siswa membaca buku yang tidak edukatif. Sekolah dapat pula menyediakan berbagai jenis buku dengan jumlah yang cukup memadai sehingga memungkinkan masing- 
masing siswa mendapatkan bahan bacaan yang diinginkannya. Buku-buku tersebut dapat diletakkan di perpustakaan sekolah, di pusatpusat belajar, maupun di kelas-kelas.

\section{Tempat Pelaksanaan DEAR}

DEAR dapat dilakukan di mana saja, baik di ruang tertutup seperti di dalam ruang kelas, perpustakaan, mushola/masjid atau aula maupun di ruang terbuka seperti lorong kelas, teras kelas, taman, halaman sekolah, atau di ruang-ruang terbuka lainnya. Jika memang memungkinkan, DEAR dilakukan di satu tempat yang bisa menampung seluruh peserta. Dengan berkumpul bersama dan masing-masing melihat semua yang berada di sekitarnya membaca, maka siswa pun akan merasa bersemangat untuk membaca.

\section{Tugas Siswa dalam DEAR}

Dalam DEAR siswa diberi waktu untuk membaca apa yang ingin mereka baca, setelah itu siswa mencatat yang telah dibaca dalam reading log. Cambourn \& Turbill (1990) dalam USAID (2015: 59) mengartikan reading log (jurnal membaca siswa) sebagai catatan harian dari kebiasaan dan ketertarikan membaca siswa yang disimpan selama periode latihan membaca mandiri. Dalam reading log siswa mencatat judul buku/bacaan, pengarang, dan tanggal membaca, serta dapat pula diberikan tambahan isian mengenai respon terhadap buku apakah buku mudah, menarik atau menantang, serta hal menarik/disukai dari buku dan sebagainya. Traci Gardner (2017) menyebutkan sesi membaca harian DEAR berlangsung antara dua puluh dan tiga puluh menit dan diikuti lima belas menit di mana siswa dapat menulis dalam reading log mereka.

Selain memberi siswa waktu untuk membaca apa yang ingin mereka baca dan menuliskannya dalam reading log, siswa juga dapat membagikan apa yang telah mereka baca, dan menerima dukungan/saran yang mereka butuhkan untuk menggali/eksplorasi bacaan dan refleksi lebih lanjut (Traci Gardner, 2017). Ketika seorang siswa menyelesaikan sebuah buku, dia dapat membahas/mendiskusikannya dengan guru dan berbagi informasi dengan siswa lain.

Namun ada hal yang harus diingat dan ditekankan dalam DEAR, yakni DEAR lebih ditekankan pada penanaman konsep dalam diri anak bahwa kegiatan membaca sebagai sesuatu yang menyenangkan, membaca dalam DEAR bukanlah membaca sebagai kegiatan akademik (Mortimer Adler, 2017). Berdasarkan hal tersebut dapat dilihat bahwa dalam pelaksanaannya DEAR seharusnya tidak membebani siswa. Penugasan-penugasan yang disebutkan di atas hendaknya tidak menjadi sebuah tuntutan yang wajib dilakukan siswa. Apabila siswa merasa terbebani, maka DEAR tidak akan disenangi. Dengan demikian, kita tidak bisa berharap program DEAR akan berhasil menciptakan budaya membaca pada anak.

\section{Peran Guru dalam DEAR}

Peran guru ketika DEAR dilaksanakan adalah guru juga ikut membaca senyap buku yang telah dipilih dan diminati bersama dengan seluruh siswa. Guru adalah teladan bagi siswa. Siswa akan memperhatikan yang dilakukan guru. Apabila siswa melihat guru membaca, mereka pun mau ikut membaca.

Selain sebagai teladan bagi siswa, guru juga sebagai motivator. Guru harus mendorong kecintaan siswa terhadap buku dan membaca. Salah satu cara yang dapat digunakan untuk mendorong siswa membaca adalah dengan cara membacakan kutipan dari berbagai buku 
dengan keras ke kelas dan menunjukkan bahwa buku tersebut tersedia di perpustakaan, tunjukkan pada siswa bahwa guru menempatkan prioritas pada membaca (Mortimer Adler, 2107). Kegiatan ini sebaiknya dilakukan di luar waktu pelaksanaan DEAR, sehingga tidak mengganggu kegiatan membaca senyap.

Guru juga berperan sebagai fasilitator, berbagi informasi kepada siswa tentang apa yang telah siswa baca. Guru menjadi tempat rujukan dan diskusi siswa untuk menanyakan hal-hal yang belum mereka pahami dalam bacaan.

Pada saat DEAR berlangsung, guru juga harus memastikan bahwa masing-masing siswa membaca tanpa diganggu yang lain. Pada saat DEAR guru ikut membaca sambil mengamati perilaku siswa. Jika ada siswa yang membaca sambil bergumam atau mengganggu yang lain, guru bisa mencatatnya untuk kemudian membahasnya setelah kegiatan selesai (USAID, 2015: 39). Cara yang dapat dilakukan guru untuk memastikan bahwa masing-masing siswa membaca tanpa diganggu yang lain adalah dengan menerapkan aturan untuk waktu DEAR. Aturan ini sebaiknya juga disampaikan diluar waktu pelaksanaan DEAR. Beberapa aturan untuk waktu DEAR seperti yang disampaikan Alta Allen (2017) meliputi: (1) semua orang di ruangan itu harus membaca buku pilihan mereka, (2) buku harus dipilih jauh sebelum waktu DEAR dimulai, (3) Tidak bangun setelah waktu DEAR dimulai, (4) Tidak berbicara atau melakukan gerakan yang mengganggu selama waktu DEAR, (5) setiap orang harus membaca tanpa suara, (6) tidak ada interupsi. Dengan aturan-aturan tersebut diharapkan pelaksanaan DEAR dapat berjalan dengan baik.

\section{Pelaksanaan DEAR di Sekolah Dasar (MI)}

Sebelum program DEAR dilaksanakan, sekolah perlu mempersiapkan beberapa hal seperti yang disebutkan USAID (2015: 3637). Hal yang perlu dipersiapkan adalah memberikan informasi kepada seluruh warga sekolah terutama siswa tentang rencana penerapan program DEAR, apa maksud dan tujuan DEAR, sehingga semua warga sekolah paham pentingnya DEAR dilakukan. Hal selanjutnya yang dilakukan adalah menentukan waktu pelaksanaan DEAR secara konsisten. Waktu DEAR dilaksanakan secara rutin, misalnya setiap hari pada pukul 06.45 hingga pukul 07.00. Penentuan waktu ini dimaksudkan agar seluruh warga sekolah terkondisi untuk siap mengikuti DEAR setiap tiba waktu pelaksanaannya. Tempat pelaksanaan DEAR juga harus ditentukan dan dipersiapkan, misalnya di dalam kelas atau di ruang terbuka, atau jika memungkinkan dapat dilakukan di halaman sekolah, aula sekolah atau terasteras kelas yang dapat menampung seluruh siswa. Hal yang tidak kalah pentingnya untuk dipersiapkan adalah menentukan penanda (bel, sirine, rekaman suara, dll) yang akan digunakan sebagai tanda waktu DEAR tiba, waktu membaca serentak mulai, dan waktu membaca selesai. Aneka bahan bacaan yang sesuai untuk seluruh tingkatan siswa juga harus dipersiapkan. Sekolah perlu mengembangkan pusat-pusat dan sudut baca di lingkungan kelas maupun sekolah. Hal terakhir yang perlu disiapkan adalah jurnal membaca (reading log) yang akan dibagikan kepada masing-masing siswa untuk mencatat apa yang telah dibacanya.

Adapun langkah-langkah pelaksanaan DEAR yang disebutkan USAID (2015: 38) adalah sebagai berikut. Pada jadwal yang telah ditentukan waktu DEAR dilaksanakan, maka tanda waktu DEAR tiba dibunyikan. Seluruh warga sekolah baik siswa, guru, dan karyawan serentak menghentikan segala aktivitas dan 
langsung menuju pusat-pusat baca yang ada di sekolah. Masing-masing memilih buku yang diminati kemudian segera menuju tempat DEAR yang telah ditetapkan dan mengambil posisi duduk santai seperti yang dikehendaki. Waktu yang dibutuhkan untuk persiapan ini perlu dibatasi sesuai kondisi kelas/sekolah. Setelah semua dalam posisi siap membaca, tanda waktu membaca mulai dibunyikan. Semua serentak membaca dengan teknik membaca senyap. Waktu yang dibutuhkan untuk membaca hanya sekitar 10-20 menit. Jika terlalu lama, dikhawatirkan siswa akan merasa bosan dan tujuan DEAR tidak akan tercapai. Setelah waktu membaca habis, tanda waktu membaca selesai dibunyikan. Semua serentak menutup bacaannya, lalu masing-masing menuliskan daftar bacaannya (judul buku dan halaman yang telah dibaca) dalam reading log. Setelah itu, seluruh warga sekolah kembali ke kelas/tempat kerja.

\section{KESIMPULAN}

Membaca merupakan keterampilan yang sangat penting untuk diajarkan sejak sekolah dasar. Keterampilan membaca di sekolah dasar merupakan fondasi dasar penentu pencapaian akademik/keberhasilan siswa. Keterampilan membaca siswa sekolah dasar harus terus ditingkatkan. Keterampilan membaca siswa sekolah dasar dapat ditingkatkan melalui DEAR atau Drop Everything and Read.

DEAR merupakan kegiatan rutin meluangkan waktu sejenak meninggalkan seluruh aktivitas untuk membaca. Membaca yang dilakukan dalam DEAR adalah membaca senyap yang dilakukan secara independen oleh siswa, guru, dan seluruh warga sekolah. Membaca dalam DEAR adalah membaca untuk kesenangan. Buku atau bahan bacaan dalam DEAR dipilih sendiri oleh masingmasing individu/siswa sehingga sesuai dengan minat dan tingkat kemampuan. Buku yang dibaca siswa bukanlah buku pelajaran. Buku yang dipilih dapat berupa buku fiksi maupun nonfiksi, yang telah dipantau guru sehingga buku tersebut layak untuk dibaca siswa.

DEAR dilakukan secara rutin/terjadwal baik hari maupun jam pelaksanaannya. Waktu yang digunakan dalam DEAR sebaiknya jangan terlalu lama agar tidak menimbulkan kebosanan pada siswa, kurang lebih 15-30 menit sehari. DEAR lebih efektif jika dilaksanakan di pagi hari saat siswa masih bersemangat. DEAR dapat dilakukan di mana saja, baik di ruang tertutup seperti di dalam ruang kelas, perpustakaan, mushola/masjid atau aula maupun di ruang terbuka seperti lorong kelas, teras kelas, taman, halaman sekolah, atau di ruang-ruang terbuka lainnya.

Dalam DEAR siswa membaca buku yang mereka pilih sendiri, kemudian jika waktu membaca habis, siswa mencatat yang telah ia baca dalam reading log (jurnal membaca). Siswa juga berbagi informasi atau berdiskusi dengan teman maupun guru tentang hal yang telah mereka baca. Namun, yang perlu diingat bahwa DEAR adalah penananaman konsep pada diri siswa bahwa membaca adalah suatu kegiatan yang menyenangkan. DEAR bukanlah kegiatan akademik. Sehingga tugas-tugas siswa dalam DEAR seharusnya tidak membebani.

Saat DEAR dilaksanakan guru juga membaca bersama-sama dengan siswa. Guru merupakan teladan, motivator, dan fasilitator bagi siswa. Aturan-aturan yang harus diterapkan dalam DEAR, yaitu (1) semua orang di ruangan itu harus membaca buku pilihan mereka, (2) buku harus dipilih jauh sebelum 
waktu DEAR dimulai, (3) Tidak bangun setelah waktu DEAR dimulai, (4) Tidak berbicara atau melakukan gerakan yang mengganggu selama waktu DEAR, (5) setiap orang harus membaca tanpa suara, (6) tidak ada interupsi. $\mathrm{U} \mathrm{n} \mathrm{t} \mathrm{u} \mathrm{k}$ melaksanakan program DEAR sekolah perlu mempersiapkan: (1) memberikan informasi kepada seluruh warga sekolah terutama siswa tentang rencana penerapan program DEAR, (2) menentukan waktu pelaksanaan DEAR secara konsisten, (3) menentukan tempat pelaksanaan DEAR, (4) menentukan penanda (bel, sirine, rekaman suara, dll) yang akan digunakan sebagai tanda waktu dear tiba, waktu membaca serentak mulai, dan waktu membaca selesai, (5) menyiapkan aneka bahan bacaan yang sesuai untuk seluruh tingkatan siswa, (6) menyiapkan jurnal membaca (reading log) yang akan dibagikan kepada masing-masing siswa untuk mencatat apa yang telah dibacanya.

Langkah-langkah pelaksanaan DEAR yang dapat diterapkan di sekolah dasar adalah:

(1) tanda waktu DEAR tiba dibunyikan, seluruh warga sekolah baik siswa, guru, dan karyawan serentak menghentikan segala aktivitas dan langsung menuju pusat-pusat baca yang ada di sekolah; (2) masing-masing memilih buku yang diminati kemudian segera menuju tempat DEAR yang telah ditetapkan dan mengambil posisi duduk santai seperti yang dikehendaki; (3) tanda waktu membaca mulai dibunyikan, semua serentak membaca dengan teknik membaca senyap, waktu membaca hanya sekitar 10-20 menit (4) setelah waktu membaca habis, tanda waktu membaca selesai dibunyikan, semua serentak menutup bacaannya, lalu masing-masing menuliskan daftar bacaannya (judul buku dan halaman yang telah dibaca) dalam reading $\log$, kemudian seluruh warga sekolah kembali ke kelas/tempat kerja masing-masing.

Tujuan dari DEAR adalah untuk membiasakan siswa gemar membaca, dan menanamkan pada diri siswa bahwa membaca merupakan aktivitas yang menyenangkan. Melalui DEAR diharapkan siswa senang membaca, memiliki minat yang tinggi dalam membaca, memiliki rasa gemar membaca, menjadikan membaca sebagai kebutuhan, sehingga tercipta budaya membaca pada masingmasing siswa baik di lingkungan sekolah maupun di rumah, sehingga keterampilan membaca siswa akan meningkat.

\section{DAFTAR PUSTAKA}

Adler, Mortimer. Drop Everything and Read. Diakses dari http://www.esl4kids.net/ tips/read.html. Pada tanggal 1 Oktober 2017, Jam 21.00 WIB.

Allen, Alta. Real-world approaches to reading.

Diakses dari http://www.learnnc.org/ lp/pages/769. Pada tanggal 4 Oktober 2017, Jam 20.22 WIB.

Gardner, Traci._Lesson Plan: A Daily DEAR Program: Drop Everything, and Read!. Diakses dari http://www.readwritethink. org/classroom-resources/lesson-plans/ daily-dear-program-drop-55.html. Pada tanggal 1 Oktober 2017, Jam 22.00 WIB.

Heath, Nikki. DEAR-Drop Everything and Read. Diakses dari http:// heartoftheschool.edublogs.org/whatwe-do/reading-and-literacy/dear-dropeverything-and-read/. Pada tanggal 30 September 2017, Jam 13.00 WIB.

Maslakhah, Siti, dkk. Bahasa Indonesia (Panduan Menulis Karya Ilmiah). 
Septia Sugiarsih

Yogyakarta: Kanwa Publisher, 2011.

Rahim, Farida. Pengajaran Membaca di Sekolah Dasar. Jakarta: Bumi Aksara, 2007.

Rofi'udin, Ahmad \& Zuchdi, Darmiyati. Pendidikan Bahasa dan Sastra Indonesia di Kelas Tinggi. Surabaya: Universitas Negeri Malang, 2001.

Tarigan, Henry Gunur. Membaca Sebagai Suatu Keterampilan Berbahasa. Bandung: Angkasa, 1985.

USAID PRIORITAS. Buku Sumber untuk Dosen Lptk Pembelajaran Literasi di Sekolah Dasar/Madrasah Ibtidaiyah. Jakarta: USAID PRIORITAS, 2015.

Verner, Susan. Real World Approaches to Reading 10 Simple Strategies You Can Use Today. Diakses dari http://busyteacher.org/11907-real-worldreading-approaches-10-simple-strategies.html. Pada tanggal Pada tanggal 4 Oktober 2017, Jam 20.00 WIB. 